\title{
Comparison of Muscle and Subcutaneous Tissue Fatty Acid Composition of Bangladeshi Nondescript Deshi Bulls Finished on Pasture Diet
}

\author{
Mohammad Khairul Alam, Ziaul Hasan Rana, and Mohammad Akhtaruzzaman \\ Institute of Nutrition and Food Science, University of Dhaka, Dhaka 1000, Bangladesh \\ Correspondence should be addressed to Mohammad Khairul Alam; khairul.alam010@gmail.com
}

Received 27 November 2016; Revised 1 March 2017; Accepted 19 March 2017; Published 26 March 2017

Academic Editor: Iciar Astiasaran

Copyright (C) 2017 Mohammad Khairul Alam et al. This is an open access article distributed under the Creative Commons Attribution License, which permits unrestricted use, distribution, and reproduction in any medium, provided the original work is properly cited.

\begin{abstract}
The objective of this study was to characterize and compare the tissue-associated differences in the fatty acid profiles of intramuscular and subcutaneous fat from pasture fed nondescript deshi breed bulls of Bangladesh. The average chemical composition of the longissimus muscle was as follows: moisture $74.65 \pm 0.48 \%$, protein $21.55 \pm 0.83 \%$, intramuscular fat $2.78 \pm 0.28 \%$, and ash $1.02 \pm 0.03 \%$. There was significant evidence that the lipids of longissimus muscle from the nondescript deshi bulls had a lower content of saturated fatty acids (SFA), monounsaturated fatty acids (MUFA), and conjugated linoleic acid (CLA) and a higher content of polyunsaturated fatty acids (PUFA) compared to subcutaneous fat. Intramuscular fat also showed the highest PUFA/SFA and $\sum n-6 / \sum n-3$ fatty acids ratios and total $n-3$ and n-6 PUFAs compared to subcutaneous tissue depots. Overall findings suggest that the meat from pasture fed nondescript deshi breed can be considered as lean meat and healthy for human consumption.
\end{abstract}

\section{Introduction}

Currently, in developing countries like Bangladesh the concern about the fat and fatty acid (FA) composition of beef is increasing because some FA can adversely affect the human health and lead to the development of modern chronic diseases. The demand for beef is really high in Bangladesh because of its rich flavors and tastiness, and beef is widely consumed after poultry meat [1]. Beef is mainly consumed by middle to upper class family, while the level of beef consumption is relatively low in poor families.

Beef fats are normally considered as disease promoting food as it is believed to contain high amounts of nutritionally undesirable saturated fatty acids (SFA) and high cholesterol levels [2]. However, numerous studies concluded that only few SFAs have negative effects on human health by raising the total and low-density lipoprotein (LDL) cholesterol and can lead to cardiovascular diseases (CVD) [3]. On the other hand, beef fats also contain several bioactive substances that provide potential health benefits (such as conjugated linoleic acid,
CLA, essential omega-3 polyunsaturated fatty acids, coenzyme Q10, glutathione, and lipoic acid) [4].

Consumers tend to favor meat which has low intramuscular fat (IMF) compared to other ones with higher fat of even superior palatability [5]. The quality of fat is dependent on the levels and percentages of FAs. Considering this scenario, numerous studies were carried out in many countries to produce meat of low fat and high PUFA content especially $n-3$ PUFA [6, 7]. However, FA composition of beef is influenced by several factors, such as diet, sex, breed, age, weight, and level of fatness [8]. The FA composition of subcutaneous tissue is also influenced by the nutritional regime, the degree of the fattening, and the type of subcutaneous tissue $[3,9,10]$. The FA profiles can even vary between subcutaneous fat and muscle fat of similar anatomical position [11].

Meat from animals grazed on pasture has desirable nutritional properties and is greatly valued by consumers because of the higher levels of polyunsaturated fatty acids (PUFAs) and lower ratio of $n-6$ to n-3 PUFAs it has [12-14]. In human, the lower ratio of n-6 to n-3 PUFAs is desirable 
for lowering the risk of many chronic diseases such as CVD, cancer, inflammatory, and autoimmune diseases [15].

In Bangladesh, no previous study has been conducted on the FA composition of meat influenced by feeding strategies. Several countries in the world have their own database for fat and FA content in beef but information about fat and FA content of the beef in Bangladesh is relatively scarce. Therefore, the aim of this study was to analyze the chemical composition and FA proportions of beef finished on pasture.

\section{Materials and Methods}

2.1. Sample Collection, Experimental Design, and Diet. The experiment was conducted at the Savar, Dhaka, for a period of 90 days from 19 March to 18 June, 2016. A total number of ten $(n=10)$ nondescript deshi breed bulls were used in the study and they were purchased from the local farmers involved in the cow trade. They had an average age of 20 months and average weight of $356 \mathrm{~kg}$ at beginning of the experimental period. These bulls were raised on the grazing land of Savar, Dhaka, Bangladesh. Its geographic location is $23.85^{\circ} \mathrm{N}$ $90.26^{\circ} \mathrm{E}$. The climate of this region is classified as tropical and the precipitation is $1990 \mathrm{~mm}$. The average daily maximum and minimum temperature for this region are $33^{\circ} \mathrm{C}$ and $22^{\circ} \mathrm{C}$ in March and $34^{\circ} \mathrm{C}$ and $25.8^{\circ} \mathrm{C}$ in June.

The dominant natural vegetation in the grazing land of this area was durba (Cynodon dactylon), Dal (Hymenachne pseudointerrupta), dumur (Ficus spp.), and many other unidentified plants.

2.2. Slaughtering and Sampling. The animals were slaughtered according to traditional slaughter (neck cutting without stunning) method in June 2016 at local slaughter house, Savar, Dhaka, Bangladesh. Immediately after slaughter, the longissimus dorsi was removed from the left side of the carcasses and samples for fatty acid composition in the muscle and subcutaneous tissue (between the 12th and 13th ribs) were collected, vacuum-packed, and stored at $-20^{\circ} \mathrm{C}$ until analysis.

2.3. Analysis of Chemical Composition. Analysis of the chemical composition of the samples was carried out according to the AOAC method of analysis [16]. The moisture content was determined by drying meat samples at $105^{\circ} \mathrm{C}$ to the constant weight. The nitrogen content was determined by the standard Kjeldahl procedure and expressed as protein content (nitrogen content multiplied by 6.25). Ash content in the beef sample was estimated by heating the dried sample in a Muffle furnace at $600^{\circ} \mathrm{C}$ for $3 \mathrm{~h}$. Ash content was calculated from weight difference. The IMF content was determined using chloroform-methanol extraction method [17].

2.4. Analysis of Fatty Acids Profile. The quantification of fatty acids in the meat samples was done according to the method described as follows.

2.4.1. Lipid Extraction and Methylation. Total lipid from muscle and subcutaneous tissue samples were extracted according to the method of Folch et al. [17] using chloroform and methanol in a ratio of $2: 1$. Briefly, $10 \mathrm{~g}$ of sample was mixed with $200 \mathrm{~mL}$ of chloroform : methanol $(2: 1, \mathrm{v} / \mathrm{v})$. Then the mixture was vortexed, centrifuged, and filtered. After that the $0.9 \%$ $\mathrm{NaCl}$ solution was added to the solvent and centrifuged again to form the layers. The upper layer of the solvent was removed by siphoning and the lower layer (chloroform containing total lipids) was collected. From the collected layer, the chloroform was removed under vacuum at $40^{\circ} \mathrm{C}$ and extracted fat was collected and content was determined gravimetrically.

The FAs obtained after extraction were converted to the corresponding fatty acid methyl esters (FAMEs) according to the method described by Sukhija and Palmquist [18] with some modification. About $10 \mathrm{mg}$ of extracted fat sample (muscle and subcutaneous) was weighed by digital scale (KERN, Germany) and then was placed into screw cap test tube. Three replicates of each sample were taken. One $\mathrm{mL} n$ heptane including internal standard (C12:1) was added to the samples and mixed. Then $0.2 \mathrm{~mL}$ of sodium methylate $(25 \%)$ was added and the tube was put in a $50^{\circ} \mathrm{C}$ water bath for 10 minutes. After that, sample was cooled for about 5 minutes. Then $1.5 \mathrm{~mL}$ of freshly made methanolic $\mathrm{HCl} 10 \%$ (prepared by adding $20 \mathrm{~mL}$ of acetyl chloride to $100 \mathrm{~mL}$ of anhydrous methanol) was added and vortexed. The tube was put in a $90^{\circ} \mathrm{C}$ steam bath for 30 minutes and then the tube sample was cooled. Finally, three $\mathrm{mL}$ of $10 \% \mathrm{~K}_{2} \mathrm{CO}_{3}$ solution was added and mixed for one minute. The sample was centrifuged (Centrifuge $5415 \mathrm{R}$; Rotofix 32A, Germany) in 5 minutes at $5000 \mathrm{rpm}$. n-Heptane phase (upper phase) was transferred to the GC vial containing insert and analyzed $(1.5 \mathrm{~mL})$ using Pasteur pipettes.

2.4.2. Determination of Fatty Acid Profile. FAMEs were analyzed by gas chromatography equipped with flame ionization detection (GC-FID; HP 6890 chromatograph, HewlettPackard, Avondale, PA, USA) using capillary column ( $\mathrm{SP}^{\mathrm{TM}}$ 2560, Sigma-Aldrich) $(100 \mathrm{~m} \times 0.25 \mathrm{~mm}$ i.d., $0.2 \mu \mathrm{m} \mathrm{df})$. Briefly, the oven temperature was initially $100^{\circ} \mathrm{C}$ (held for 5 minute), then increased at $3^{\circ} \mathrm{C} \mathrm{min}^{-1}$ to $140^{\circ} \mathrm{C}$ (held for 20 minute), then increased at $8^{\circ} \mathrm{C} \mathrm{min}{ }^{-1}$ to $230^{\circ} \mathrm{C}$ (held for 10 minute), and finally increased at $6^{\circ} \mathrm{C} \mathrm{min}^{-1}$ to $240^{\circ} \mathrm{C}$ (held for 8 minute). Hydrogen was used as the carrier gas at a flow rate of $1.0 \mathrm{~mL} \cdot \mathrm{min}^{-1}$. The inlet and detector temperatures were maintained at $250^{\circ} \mathrm{C}$ and $300^{\circ} \mathrm{C}$, respectively, and $1 \mu \mathrm{L}$ was injected by the GC-FID from the vial. Identification of common FA was accomplished by comparison of sample peak retention times with those of known FAME standard mixtures (SupelcoTM 37 component FAME Mix, Supelco-189191AMP, USA). Quantification of total FAME was done using 5-dodecenoic acid (12:1) as internal standard (NU-CHEK PREP, USA). Calibration curves were constructed from the analysis of the working standards in triplicate using the same GC conditions as those used for quantitative purposes. The concentration of FAMEs in the samples was determined using the area ratio and calibration plots. The result of the evaluation was the percentage (\%) of total fatty acids (TFA).

2.5. Statistical Analysis. Results were analyzed by analysis of variance using the MIXED procedure of SAS (SAS Inst. 
TABLE 1: Characteristics of the slaughtered bulls.

\begin{tabular}{lcc}
\hline Traits & Mean & SD \\
\hline Initial weight (Kg) & 356 & 8.71 \\
Slaughter age (month) & 23 & 0.22 \\
Slaughter weight (Kg) & 535 & 5.13 \\
Hot carcass weight $(\mathrm{Kg})$ & 260 & 3.39 \\
$\mathrm{pH}$ & 5.39 & 0.11 \\
\hline
\end{tabular}

TABLE 2: Chemical composition of the LD muscle sample.

\begin{tabular}{lcc}
\hline Nutrients & Mean & SD \\
\hline Moisture & 74.65 & 0.48 \\
Protein & 21.55 & 0.83 \\
Ash & 1.02 & 0.03 \\
\hline
\end{tabular}

Inc., Cary, NC, ver. 8.2). The difference between muscle and subcutaneous tissues FA composition based on pasture diet was assessed using a one-way ANOVA in a completely randomized design with repeated measures. The model included different tissues and the interaction between tissues as fixed effects and the random effect of animals and replication within treatment. The results were expressed as Least Squares Mean (LSM) and the standard error of the mean (SEM). The effects were declared to be significant at level $p<$ 0.05 . Descriptive statistics were used for animal traits and muscle chemical composition variables and the values were expressed as mean and standard deviation (SD).

\section{Results}

3.1. Carcass Characteristics. The characteristics of the animals used in the study are presented in Table 1.

3.2. Chemical Composition of Longissimus Muscle. The chemical composition (moisture, protein, and ash) of the muscle sample is summarized in Table 2.

3.3. Fatty Acid Composition of Subcutaneous Fat and Intramuscular Fat from Longissimus Muscle. Data referring to the total fat and fatty acid profile of LD muscle and subcutaneous fats (as \% of total fatty acids) in nondescript deshi breed bulls are presented in Table 3. Highly significant differences exist between the LD muscle and subcutaneous tissues in terms of fat content (IMF, 2.78\%; subcutaneous tissue, $69.83 \%$; $p<$ 0.0001 ). Subcutaneous adipose tissue had higher percentages of SFA (47.97 versus 40.64). Of the SFA, palmitic acid (C16:0) and stearic acid (C18:0) were found to be the dominant ones in both tissue samples. Lauric acid (C12:0), myristic acid (C14:0), and palmitic acid (C16:0) were found to be the dominant one in the subcutaneous tissue compared to the intramuscular fat $(p<0.05)$; however, no difference was seen between the two types of fat in stearic acid (C18:0) content. There was also no difference in terms of C18:1cis-9 (oleic acid; the major MUFA) content and interestingly the proportion of total MUFA in the subcutaneous tissue lipids was higher than the IMF ( $p<0.001)$. C18:1cis-9 (oleic acid) was the major
MUFA in both studied tissues, comprising 35.83\% and 35.95\% in IMF and subcutaneous fat, respectively.

IMF had higher percentages of PUFA than subcutaneous adipose tissue (13.90 versus 2.65) due to the higher percentage of the individual n-3 (C18:3n-3; C20:3n-3; C20:5n-3; and C22:6n-3) and n-6 (C18:2trans-9, trans-12; C18:2n-6; C18:3n6; C20:2n-6; C20:3n-6; C20:4n-6; and C22:2n-6) fatty acids $(p<0.05)$ (Table 3). The level of essential fatty acids (LA, C18:2n-6; ALA, C18:3n-3) is higher in IMF than the subcutaneous fat. The same statement is also true for arachidonic acid (C20:4n-6), EPA (C20:5n-3), DPA (22:5n-3), and DHA (C22:6n-3).

CLA proportion was higher in the subcutaneous fat than the muscle fat $(0.85 \%$ versus $0.35 \%)$. Percentages of sum $n$ 3 and n-6 PUFAs were significantly higher in the muscle fat compared to subcutaneous fat. IMF also showed higher value of $\Sigma$ n-6/ $\Sigma$ n-3 PUFA ratio than the subcutaneous fat (2.10 versus 1.63). In subcutaneous fat there was high percentage of the VA (C18:1trans-11), (2.87\%) compared to IMF (1.54\%).

\section{Discussion}

Considering that the present study was first attempt at estimating the chemical and FA composition of Bangladeshi beef finished on pasture, no data was available for national level comparison. In many countries the IMF content $<5 \%$ is considered as being "low in fat" meat [3]. Therefore, according to our findings (Table 3) longissimus dorsi muscle of nondescript deshi breed bulls of Bangladesh could be classified as lean meat. In concomitant with this, muscle tissue after removal of any visible fat ( $<5 \%$ fat) would normally satisfy for incorporation into a healthy diet. The chemical composition and IMF of Bangladeshi pastured beef (Tables 2 and 3) are close to most of the European, Australian, and American pastured beef $[8,19-21]$.

Many studies have reported that replacing saturated fat and transfatty acids with unsaturated fat, especially n-3 fatty acids, is more effective in lowering the risk of coronary heart disease than simply reducing total fat consumption [22]. Feeding strategies that lead to a decrease in saturated fat and enhancing the $n-3$ PUFAs of intramuscular fat would produce the beef of more positive nutritional value. Several studies have reported that dietary fat content of the animals is the major factor primarily causing the changes of FA composition in the meat and adipose fat [19]. Beef cattles raised on grass or pasture feeding are considered to have lean meat together with FA composition suitable for human nutrition [19].

In our study, the predominant fatty acids in both the IMF and subcutaneous fat were C16:0 and C18:0 as SFA, C18:1cis9 as MUFA, and C18:2n- 6 as PUFA which is an agreement with the results found by Poulson et al. [23] who studied the FA profile of steers raised on grass feeding. Nevertheless, the comparison of results is difficult because FA profiles are affected by breed, sex, level of fatness, and slaughter age besides the feeding method [8].

In this study, we observed a significant depot effect on the FA composition. IMF displayed significantly lower percentages of C12:0, C14:0, C15:0, C16:0, SFA, and MUFA and 
TABLE 3: Total fat (\%) and fatty acid (\% of total fatty acids) composition of subcutaneous and LD muscle from nondescript deshi bulls fed on pasture.

\begin{tabular}{|c|c|c|c|c|}
\hline \multirow[b]{2}{*}{ Total fat and fatty acids } & \multicolumn{2}{|c|}{ Tissue type } & \multirow[b]{2}{*}{ SEM } & \multirow[b]{2}{*}{$p$ value } \\
\hline & $\begin{array}{l}\text { Muscle } \\
(n=10)\end{array}$ & $\begin{array}{l}\text { Subcutaneous } \\
\quad(n=10)\end{array}$ & & \\
\hline Total fat & 2.78 & 69.83 & 0.28 & $<0.001$ \\
\hline \multicolumn{5}{|l|}{ Fatty acids } \\
\hline C8:0 & 0.19 & 0.0001 & 0.06 & 0.037 \\
\hline $\mathrm{C} 10: 0$ & 0.03 & 0.06 & 0.01 & 0.273 \\
\hline $\mathrm{C} 12: 0$ & 0.05 & 0.11 & 0.01 & $<0.001$ \\
\hline $\mathrm{C} 13: 0$ & 0.002 & 0.02 & 0.003 & 0.001 \\
\hline C14:0 & 2.10 & 3.88 & 0.18 & $<0.001$ \\
\hline $\mathrm{C} 15: 0$ & 0.45 & 1.28 & 0.06 & $<0.001$ \\
\hline $\mathrm{C} 16: 0$ & 23.66 & 27.33 & 0.71 & 0.004 \\
\hline $\mathrm{C} 18: 0$ & 14.34 & 15.31 & 1.12 & 0.634 \\
\hline C18:1trans-9 & 0.24 & 2.82 & 0.18 & $<0.001$ \\
\hline C18:1trans-11 & 1.54 & 2.87 & 0.12 & $<0.001$ \\
\hline C18:1cis-9 & 35.83 & 35.95 & 1.44 & 0.983 \\
\hline C18:2trans- 6 & 0.17 & 0.08 & 0.02 & 0.004 \\
\hline $\mathrm{C} 18: 2 c i s-6$ & 5.69 & 1.34 & 0.63 & $<0.001$ \\
\hline$C 18: 3 n-6$ & 0.07 & 0.03 & 0.01 & 0.015 \\
\hline $\mathrm{C} 18: 3 n-3$ & 2.47 & 0.88 & 0.23 & $<0.001$ \\
\hline CLAcis-9, trans-11 & 0.35 & 0.85 & 0.05 & $<0.001$ \\
\hline $\mathrm{C} 20: 0$ & 0.13 & 0.41 & 0.03 & $<0.001$ \\
\hline $\mathrm{C} 20: 1$ & 0.16 & 0.21 & 0.02 & 0.018 \\
\hline$C 20: 2 n-6$ & 0.11 & 0.08 & 0.01 & 0.084 \\
\hline$C 20: 3 n-6$ & 0.62 & 0.06 & 0.07 & $<0.001$ \\
\hline$C 20: 3 n-3$ & 0.08 & 0.03 & 0.01 & $<0.001$ \\
\hline$C 20: 4 n-6$ & 2.38 & 0.04 & 0.02 & $<0.001$ \\
\hline$C 20: 5 n-3$ & 0.53 & 0.03 & 0.01 & $<0.001$ \\
\hline C22:1n-9 & 0.03 & 0.13 & 0.01 & $<0.001$ \\
\hline$C 22: 2 n-6$ & 0.36 & 0.05 & 0.04 & $<0.001$ \\
\hline C24:1 & 0.05 & 0.04 & 0.01 & 0.621 \\
\hline$C 22: 5 n-3$ & 1.12 & 0.08 & 0.01 & $<0.001$ \\
\hline$C 22: 6 n-3$ & 0.28 & 0.01 & 0.03 & $<0.001$ \\
\hline$\sum \mathrm{SFA}^{1}$ & 40.64 & 47.97 & 1.27 & 0.003 \\
\hline$\sum \mathrm{MUFA}^{2}$ & 37.85 & 41.98 & 1.34 & $<0.001$ \\
\hline$\sum \mathrm{PUFA}^{3}$ & 13.90 & 2.65 & 0.01 & $<0.001$ \\
\hline$\sum \mathrm{PUFA} / \sum \mathrm{SFA}$ & 0.34 & 0.05 & 0.01 & $<0.001$ \\
\hline$\sum n-3^{4}$ & 4.48 & 1.02 & 0.02 & $<0.001$ \\
\hline$\sum \mathrm{n}-6^{5}$ & 9.42 & 1.66 & 0.01 & $<0.001$ \\
\hline$\sum n-6 / \sum n-3$ & 2.10 & 1.63 & 0.01 & $<0.001$ \\
\hline
\end{tabular}

${ }^{1}$ Sum of saturated fatty acids: C8:0 + C10:0 + C12:0 + C13:0 + C14:0 + C15:0 + C16:0 + C18:0 + C20:0.

${ }^{2}$ Sum of monounsaturated fatty acids: C18:1trans-9 + C18:1 trans-11 + C18:1cis-9 + C20:1 + C22:1 + C24:1.

${ }^{3}$ Sum of n-3 and n- 6 fatty acids.

${ }^{4}$ Sum of n-3 fatty acids: C18:3n-3 + C20:3n-3 + C20:5n-3 + C22:5n-3 + C22:6n-3.

${ }^{5}$ Sum of n-6 fatty acids: C18:2trans- $6+$ C18:2cis- $6+$ C18:3n- $6+$ C20:2n-6 + C20:3n-6 + C20:4n-6 + C22:2n-6. 
greater percentages of C18:2n-6, C18:3n-3, C18:3n-6, C20:4n6, C20:5n-3, C22:5n-3, C22:6n-3, PUFA, and total n-3 PUFA, total n-6 PUFA, and PUFA/SFA and $\sum n-6 / \sum n-3$ PUFA ratios compared with samples from subcutaneous fat which is in concomitant with the findings of Aldai et al. [24]. In contrast, Webb et al. [25] found higher percentages of SFA in lipids of muscle tissue compared with subcutaneous fat. In both of these studies, authors reported higher level of C18:0 in subcutaneous fat than IMF but we did not observe this trend in our study. High MUFA proportion in the subcutaneous fat compared to the IMF has been previously stated and may be the result of elevated stearoyl-CoA- $\Delta 9$-desaturase activity which converts $\mathrm{C} 14: 0, \mathrm{C} 16: 0$, and C18:0 to their corresponding MUFAs [26].

The subcutaneous fat showed greater percentages of CLA than IMF (0.85 versus 0.35 ), which is in agreement with the results obtained by Aldai et al. [24]. CLA values were similar to those obtained from pasture systems and higher than those obtained in feedlots systems [27, 28].

PUFA percentage in IMF was significantly greater $(p<$ $0.001)$ than in subcutaneous adipose tissue and this is documented in the comparatively high contents of n-6 and n-3 PUFAs but not for CLA. Previous studies also reported the similar result $[24,29,30]$. The reason for this may be the preferable incorporation of long chain n-3 fatty acids from pasture into muscle tissue (polar lipids) compared to subcutaneous tissue (neutral lipids) [31]. This study also demonstrated that pasture diet resulted in increase in EPA, DPA, and DHA percentages in muscle tissue but not in subcutaneous tissue. Moreover, the smaller adipocyte size and a higher ratio of phospholipid to neutral lipid have also been indicated for increased PUFA content in IMF than subcutaneous adipose tissue fat [24].

Aldai et al. [24] reported that n-6/n-3 PUFAs ratio is significantly higher in IMF than the subcutaneous fat and we also found similar result in this study (2.10 versus 1.63 ; $p<0.001)$.

PUFA/SFA and n-6/n-3 PUFAs ratios are frequently used to evaluate the nutritional value and consumer health of IMF. However, an index such as PUFA/SFA may not be a suitable indicator to assess the nutritional value of fat because some SFAs do not elevate plasma cholesterol and overlook the effects of MUFAs [32]. UK department of health [33] recommended that the PUFA/SFA and n-6/n-3 PUFAs ratios in meat should be around 0.45 and $<4$, respectively. Therefore, our findings in this study were significantly lower than the recommended values [33]. However, the PUFA/SFA ratio for beef is typically low at around 0.1 [34] and the value is about 0.5-0.7 for double muscled animals as meat from these animals generally has very low $\operatorname{IMF}(<1 \%)[25,35]$. Besides the IMF, FA composition is also different in double muscled animals compared to nondouble muscled animals. Typically, double muscled animals have higher concentration of PUFA and lower concentration of SFA, thereby having higher PUFA/SFA ratio compared to nondouble muscled counterparts $[25,35]$. Double muscled animals also showed different pattern of metabolism of n-6 and n-3 PUFAs; especially the deposition rate of $n-3$ fatty acids in these animals is greater than the nondouble muscled animals.

\section{Conclusion}

The effect of pasture feeding on the FA profile of beef may not be generalized easily as it appears that numerous meat FAs are affected by both breed and type of grass. As little information was available on the nutrient content and FA composition of Bangladeshi beef, the results of this study contribute considerably to much needed information on the FA composition of grass fed beef in Bangladesh.

\section{Conflicts of Interest}

The authors declare that they have no conflicts of interest.

\section{References}

[1] OECD/FAO, OECD-FAO Agricultural Outlook 2016-2025, OECD Publishing, Paris, France, 2016.

[2] E. J. Schaefer, "Lipoproteins, nutrition, and heart disease," American Journal of Clinical Nutrition, vol. 75, no. 2, pp. 191-212, 2002.

[3] S. Renaud and D. Lanzmann-Petithory, "Dietary fats and coronary heart disease pathogenesis," Current Atherosclerosis Reports, vol. 4, no. 6, pp. 419-424, 2002.

[4] P. Williams, "Nutritional composition of red meat," Nutrition and Dietetics, vol. 64, no. 4, pp. S113-S119, 2007.

[5] G. Holló, J. Csapó, E. Szucs, J. Tözsér, I. Repa, and I. Holló, "Influence of breed, slaughter weight and gender on chemical composition of beef. Part 2. Fatty acid composition of fat in rib samples," Asian-Australasian Journal of Animal Sciences, vol. 14, no. 12, pp. 1719-1723, 2001.

[6] N. D. Scollan, N.-J. Choi, E. Kurt, A. V. Fisher, M. Enser, and J. D. Wood, "Manipulating the fatty acid composition of muscle and adipose tissue in beef cattle," British Journal of Nutrition, vol. 85, no. 1, pp. 115-124, 2001.

[7] A. P. Moloney, M. T. Mooney, J. P. Kerry, C. Stanton, and P. O'Kiely, "Colour of fat, and colour, fatty acid composition and sensory characteristics of muscle from heifers offered alternative forages to grass silage in a finishing ration," Meat Science, vol. 95, no. 3, pp. 608-615, 2013.

[8] C. A. Daley, A. Abbott, P. S. Doyle, G. A. Nader, and S. Larson, "A review of fatty acid profiles and antioxidant content in grassfed and grain-fed beef," Nutrition Journal, vol. 9, no. 1, article 10, 2010.

[9] S. K. Duckett, D. G. Wagner, L. D. Yates, H. G. Dolezal, and S. G. May, "Effects of time on feed on beef nutrient composition," Journal of Animal Science, vol. 71, no. 8, pp. 2079-2088, 1993.

[10] Y. Aharoni, E. Nachtomi, P. Holstein, A. Brosh, Z. Holzer, and Z. Nitsan, "Dietary effects on fat deposition and fatty acid profiles in muscle and fat depots of Friesian bull calves," Journal of Animal Science, vol. 73, no. 9, pp. 2712-2720, 1995.

[11] E. H. Callow, "Comparative studies of meat. VIII. The percentage of fat in the fatty and muscular tissues of steers and the iodine number of the extracted fat, as affected by breed and level of nutrition," The Journal of Agricultural Science, vol. 58, no. 3, pp. 295-307, 1962.

[12] A. Schmid, M. Collomb, R. Sieber, and G. Bee, "Conjugated linoleic acid in meat and meat products: a review," Meat Science, vol. 73, no. 1, pp. 29-41, 2006.

[13] J. R. Fincham, J. P. Fontenot, W. S. Swecker et al., "Fatty acid metabolism and deposition in subcutaneous adipose tissue of 
pasture- and feedlot-finished cattle," Journal of Animal Science, vol. 87, no. 10, pp. 3259-3277, 2009.

[14] S. K. Duckett, J. P. S. Neel, R. M. Lewis, J. P. Fontenot, and W. M. Clapham, "Effects of forage species or concentrate finishing on animal performance, carcass and meat quality," Journal of Animal Science, vol. 91, no. 3, pp. 1454-1467, 2013.

[15] A. P. Simopoulos, "The importance of the omega-6/omega-3 fatty acid ratio in cardiovascular disease and other chronic diseases," Experimental Biology and Medicine, vol. 233, no. 6, pp. 674-688, 2008.

[16] AOAC, Official Method of Analysis. Association of Official Analytical Chemist, AOAC International, Rockville, Md, USA, 19th edition, 2012.

[17] J. Folch, M. Lees, and G. H. S. Stanley, "A simple method for the isolation and purification of total lipides from animal tissues," The Journal of Biological Chemistry, vol. 226, no. 1, pp. 497-509, 1957.

[18] P. S. Sukhija and D. L. Palmquist, "Rapid method for determination of total fatty acid content and composition of feedstuffs and feces," Journal of Agricultural and Food Chemistry, vol. 36, no. 6, pp. 1202-1206, 1988.

[19] K. Nuernberg, D. Dannenberger, G. Nuernberg et al., "Effect of a grass-based and a concentrate feeding system on meat quality characteristics and fatty acid composition of longissimus muscle in different cattle breeds," Livestock Production Science, vol. 94, no. 1-2, pp. 137-147, 2005.

[20] J. M. Leheska, L. D. Thompson, J. C. Howe et al., "Effects of conventional and grass-feeding systems on the nutrient composition of beef," Journal of Animal Science, vol. 86, no. 12, pp. 3575-3585, 2008.

[21] A. Brugiapaglia, C. Lussiana, and G. Destefanis, "Fatty acid profile and cholesterol content of beef at retail of Piemontese, Limousin and Friesian breeds," Meat Science, vol. 96, no. 1, pp. 568-573, 2014.

[22] T. A. B. Sanders, "High-versus low-fat diets in human diseases," Current Opinion in Clinical Nutrition and Metabolic Care, vol. 6, no. 2, pp. 151-155, 2003.

[23] C. S. Poulson, T. R. Dhiman, A. L. Ure, D. Cornforth, and K. C. Olson, "Conjugated linoleic acid content of beef from cattle fed diets containing high grain, CLA, or raised on forages," Livestock Production Science, vol. 91, no. 1-2, pp. 117-128, 2004.

[24] N. Aldai, A. I. Nájera, M. E. R. Dugan, R. Celaya, and K. Osoro, "Characterisation of intramuscular, intermuscular and subcutaneous adipose tissues in yearling bulls of different genetic groups," Meat Science, vol. 76, no. 4, pp. 682-691, 2007.

[25] E. C. Webb, S. De Smet, C. Van Nevel, B. Martens, and D. I. Demeyer, "Effect of anatomical location on the composition of fatty acids in double-muscled Belgian blue cows," Meat Science, vol. 50, no. 1, pp. 45-53, 1998.

[26] L. C. St John, D. K. Lunt, and S. B. Smith, "Fatty acid elongation and desaturation enzyme activities of bovine liver and subcutaneous adipose tissue microsomes," Journal of Animal Science, vol. 69, no. 3, pp. 1064-1073, 1991.

[27] C. M. M. Alfaia, V. S. S. Ribeiro, M. R. A. Lourenço et al., "Fatty acid composition, conjugated linoleic acid isomers and cholesterol in beef from crossbred bullocks intensively produced and from Alentejana purebred bullocks reared according to Carnalentejana-PDO specifications," Meat Science, vol. 72, no. 3, pp. 425-436, 2006.

[28] C. E. Realini, S. K. Duckett, G. W. Brito, M. Dalla Rizza, and D. De Mattos, "Effect of pasture vs. concentrate feeding with or without antioxidants on carcass characteristics, fatty acid composition, and quality of Uruguayan beef," Meat Science, vol. 66 , no. 3, pp. $567-577,2004$.

[29] T. Jiang, C. J. Mueller, J. R. Busboom, M. L. Nelson, J. O’Fallon, and G. Tschida, "Fatty acid composition of adipose tissue and muscle from Jersey steers was affected by finishing diet and tissue location," Meat Science, vol. 93, no. 2, pp. 153-161, 2013.

[30] G. Indurain, M. J. Beriain, M. V. Goñi, A. Arana, and A. Purroy, "Composition and estimation of intramuscular and subcutaneous fatty acid composition in Spanish young bulls," Meat Science, vol. 73, no. 2, pp. 326-334, 2006.

[31] F. Noci, F. J. Monahan, P. French, and A. P. Moloney, “The fatty acid composition of muscle fat and subcutaneous adipose tissue of pasture-fed beef heifers: influence of the duration of grazing," Journal of Animal Science, vol. 83, no. 5, pp. 1167-1178, 2005.

[32] J. Santos-Silva, R. J. B. Bessa, and F. Santos-Silva, "Effect of genotype, feeding system and slaughter weight on the quality of light lambs. II. Fatty acid composition of meat," Livestock Production Science, vol. 77, no. 2-3, pp. 187-194, 2002.

[33] British Department of Health, "Nutritional aspects of cardiovascular diseases," Report on Health and Social Subjects 46, HMSO, London, UK, 1994.

[34] N. Scollan, J.-F. Hocquette, K. Nuernberg, D. Dannenberger, I. Richardson, and A. Moloney, "Innovations in beef production systems that enhance the nutritional and health value of beef lipids and their relationship with meat quality," Meat Science, vol. 74, no. 1, pp. 17-33, 2006.

[35] K. Raes, S. De Smet, A. Balcaen, E. Claeys, and D. Demeyer, "Effect of diets rich in N-3 polyunsaturated fatty acids on muscle lipids and fatty acids in Belgian Blue double-muscled young bulls," Reproduction Nutrition Development, vol. 43, no. 4, pp. 331-345, 2003. 

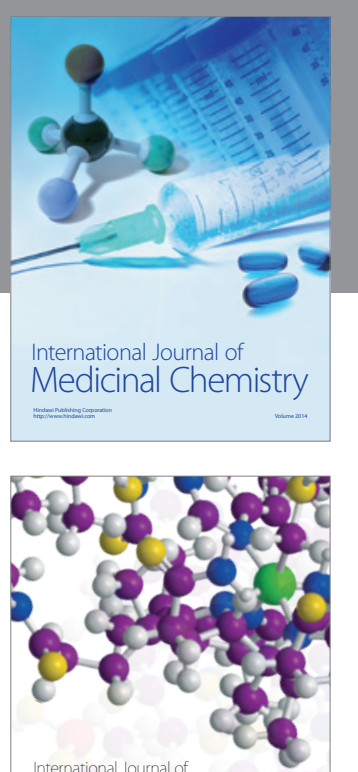

Carbohydrate Chemistry

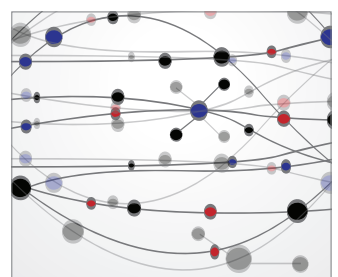

The Scientific World Journal
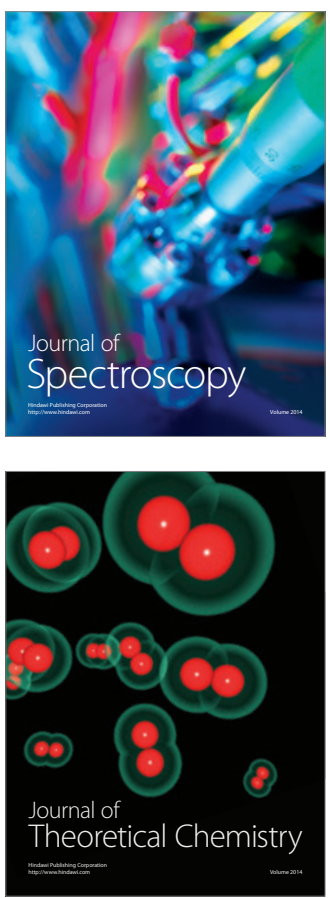
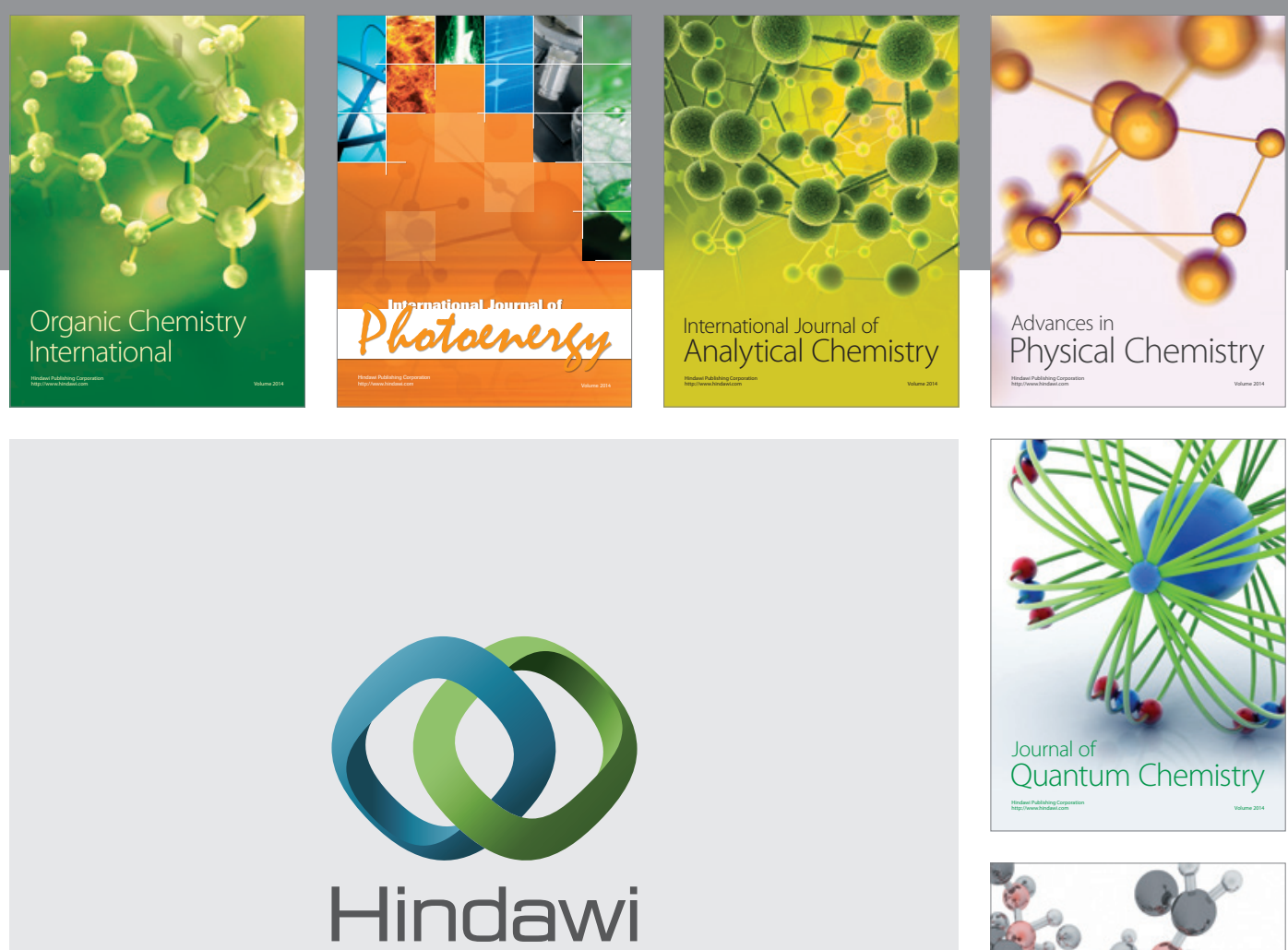

Submit your manuscripts at

https://www.hindawi.com

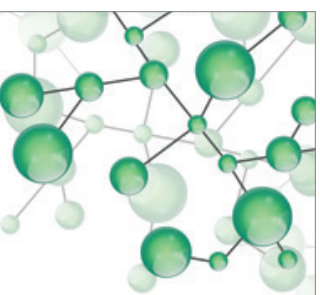

International Journal of

Inorganic Chemistry
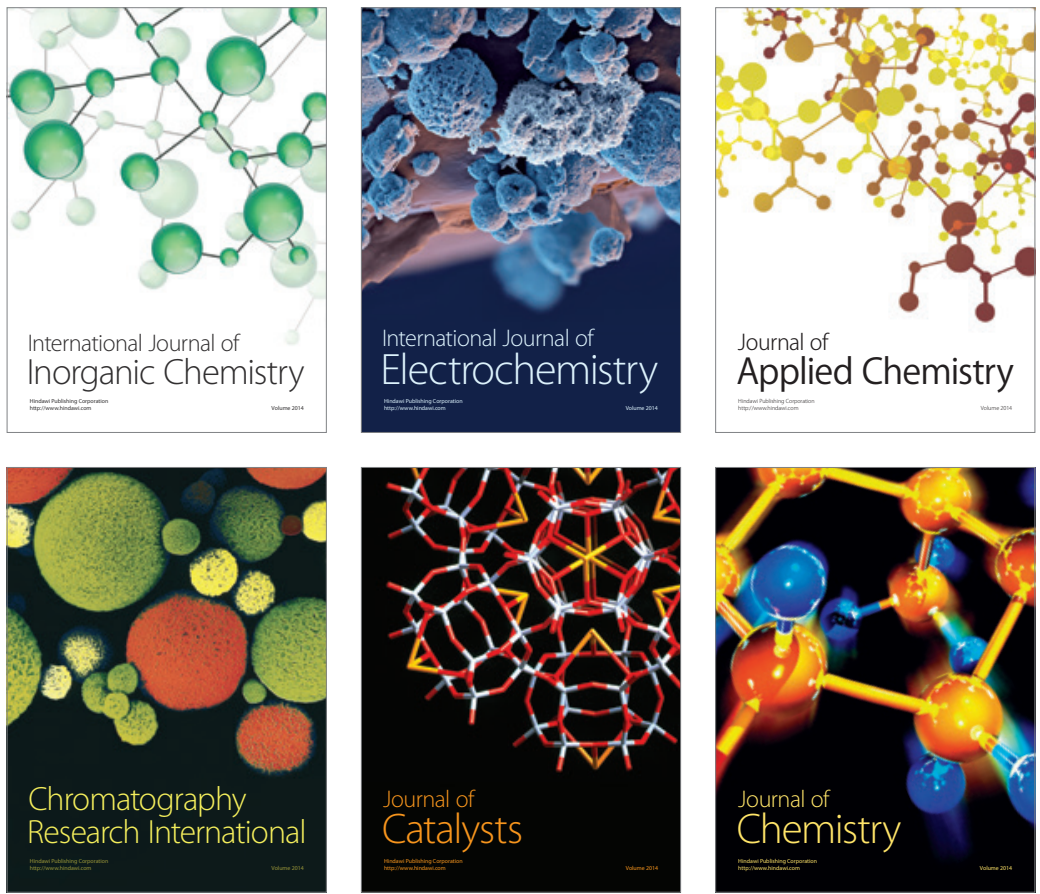

Journal of

Applied Chemistry
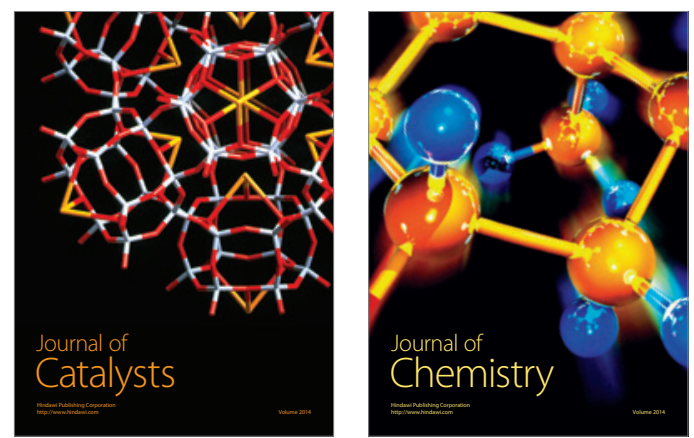
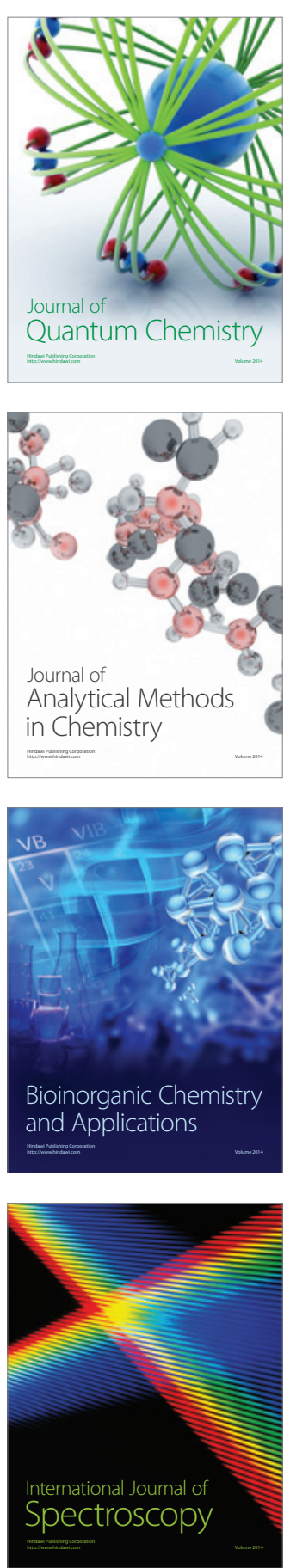